PERM JOURNAL OF PETROLEUM AND MINING ENGINEERING ВЕСТНИК ПНИПУ. ГЕОЛОГИЯ. НЕФТЕГАЗОВОЕ И ГОРНОЕ ДЕЛО ISSN 2224-9923 Volume/ Tom 19 №4, 2019

http://vestnik.pstu.ru/geo/

UDC 622.276:658.562

Article / Статья

(C) PNRPU / ПНИПУ, 2019

\title{
POSSIBILITIES FOR IN-OPERATION CONTROL OF REMAINING RECOVERABLE RESERVES AT VARIOUS STAGES OF OIL PRODUCTION OBJECTS DEVELOPMENT
}

\section{S.V. Galkin, T.B. Poplaukhina, N.G. Luzina1, D.S. Lobanov', R.I. Emashov ${ }^{1}$}

Perm National Research Polytechnic University (29 Komsomolskiy av., Perm, 614990, Russian Federation)

${ }^{1}$ PermNIPIneft branch of LUKOIL-Engineering LLC in Perm (3a Permskaya st., Perm, 614066, Russian Federation)

\section{ВОЗМОЖНОСТИ ОПЕРАТИВНОГО КОНТРОЛЯ ОСТАТОЧНЫХ ИЗВЛЕКАЕМЫХ ЗАПАСОВ НА РАЗЛИЧНЫХ СТАДИЯХ РАЗРАБОТКИ НЕФТЯНЫХ ЭКСПЛУАТАЦИОННЫХ ОБЪЕКТОВ}

\section{С.В. Галкин, Т.Б. Поплаухина, Н.Г. Лузина ${ }^{1}$, Д.С. Лобанов ${ }^{1}$, Р.И. Емашов ${ }^{1}$}

Пермский национальный исследовательский политехнический университет (614990, Россия, г. Пермь, Комсомольский проспект, 29) 'Филиал ООО «ЛУКОЙЛ-Инжиниринг “ПермНИПИнефть”» в г. Перми (614066, Россия, г. Пермь, ул. Пермская, 3а) Received / Получена: 23.07.2019. Accepted / Принята: 01.11.2019. Published / Опубликована: 27.12.2019

Key words:

remaining recoverable reserves, oil recovery factor, production object, oilfield development design, geological and financial estimation of reserves, displacement characteristics, oil production decline rate.

\begin{abstract}
Estimation of oil recovery factors on the basis of geological and hydrodynamic simulation is very cost- and timeconsuming. As a result, re-estimation of recoverable hydrocarbon reserves is performed over long periods of time without any more short-term corrections of estimates. The approved oil recovery factors can become outdated due to the changes in the economic conditions of development or a misalignment between actual development and design conditions. For reliable estimation of remaining recoverable reserves at oil production objects, it is critically important to establish in-operation control of oil recovery factors reliability, including their objective achievability within specific time frames.

Based on the example of Perm region oilfields, the paper analyzes the practice of annual geological and financial estimation of the Based on the example of Perm region oilfields, the paper analyzes the practice of annual geological and financial estimation of the reserves according to international standards. A conclusion has been made that it is necessary to perform similar control of recoverable oil reserves estimated as per the Russian classification. Several options of in-operation control are available for approved oil recovery factors: use of analog-statistical methods, displacement characteristics, production decline rate analysis. The methods are based on various physical regularities, their effectiveness to a large extent depending on the quality of input information and the stage of the production object development, as well as on the economic conditions.

Case studies are used to analyze the effectiveness of control of the approved oil recovery factors. For early development stages, use of multivariate analog-statistical dependencies drawn from geological parameters built for specific production objects was found to be the most effective method. The long history of Perm Krai oil fields development and a relatively large number of production objects at late stages of recovery make this statistic approach feasible.

At late stages, more reliability can be obtained by using methods based on the displacement characteristics and oil production decline rate taking into account the economic limit of development. The suggested control method involves use of statistic dependencies relying on both geological and technological parameters. Comprehensive use of multiple method approaches helps achieve a more reliable estimation of the remaining recoverable reserves at the production objects.
\end{abstract}

Ключевые слова: остаточные извлекаемые запасы, коэффициент извлечения нефти, эксплуатационный объект, проектирование разработки нефтяных месторождений, геолого-экономическая оценка запасов, характеристики вытеснения, темп падения добычи нефти.
Оценка коэффициентов извлечения нефти на основе геолого-гидродинамического моделирования требует больших финансовых и временных затрат. В результате пересчеты извлекаемых запасов углеводородов выполняются через длительное время и в пределах значительных временных интервалов их оценки не корректируются. Утвержденные коэффициенты извлечения нефти могут значительно терять актуальность в связи с изменением экономических условий разработки или несоответствием фактических условий разработки проектным. Для достоверной оценки остаточньх извлекаемых запасов нефтяных эксплуатационных объектов крайне важно оперативно контролировать обоснованность коэффищиентов извлечения нефти, в том числе его объективную достижимость в конкретные временные сроки.

В статье на примере нефтяных месторождений Пермского региона выполнен анализ практики проведения ежегодной геолого-экономической оценки запасов по международным стандартам. Сделан вывод о необходимости аналогичного контроля извлекаемых запасов нефти, подсчитываемых по российской классификации. Известно несколько направлений оперативного контроля оценки утвержденных коэффициентов извлечения нефти: применение аналого-статистических методов, характеристик вытеснения, анализ темпов падения добычи. Методы основаны на различных физических закономерностях, их эффективность во многом зависит от качества исходной информации и стадии разработки эксплуатационного объекта, от экономических условий.

На конкретных примерах рассмотрена эффективность контроля утвержденных коэффициентов извлечения нефти Для ранних стадий разработки при этом наиболее эффективно применение многомерных аналого-статистических зависимостей на основе геологических показателей, построенных для конкретных эксплуатационных объектов. Длительный период разработки месторождений Пермского края и достаточно большое количество объектов, находящихся на поздних стадиях выработки, позволяют реализовать такой статистический подход.

На поздних стадиях большую достоверность приобретают методы на основе характеристик вытеснения и темпов падения добычи нефти с учетом экономического предела рентабельности разработки. В качестве контроля могут быть использованы статистические зависимости с привлечением не только геологических, но и технологических показателей. Комплексное использование различных методических подходов позволяет более надежно оценить остаточные извлекаемые запасы эксплуатационных объектов.

Sergey V. Galkin (AuthorID in Scopus: 36711675500) - Doctor of Geology and Mineralogy, Professor, Dean of the Mining and Oil Faculty (tel.: +007 902 631 20 13, e-mail: doc galkin(mail.ru). The contact person for correspondence.

Tatyana B. Poplaukhina (Author ID in Scopus: 36712371500) - PhD in Engineering, Associate Professor, PhD in Engineering (tel.: +007 342 219 82 07, e-mail: poplaukhinatb $($ a)gmail.com)

Nina G. Luzina (Author ID in Scopus: 55531632200 ) - Leading Engineer of the Department of Geological and Economic Assessment of Field Reserves (tel.: +007 342 233 61 94 , e-mail: Nina.Luzina $(a$ pnnn.lukoil.com)

Dmitriy S. Lobanov $-1^{\text {st }}$ Category Engineer of the Department of Geological and Economic Assessment of Field Reserves (tel.: +0073422336193 , Dmitriy S. Lobanov $-1^{\text {st }}$ Category E
e-mail: Dmitrii.Lobanov $a$,pnn.lukoil.com).

Roman I. Emashov - Head of the Department of Geological and Economic Assessment of Field Reserves (tel.: +007 34223361 99, e-mail: Roman.Emashov@pnn.lukoil.com). Галкин Сергей Владиславович - доктор геолого-минералогических наук, профессор кафедры нефтегазовых технологий (тел.: +007 9026312013 , e-mail: doc galkin $@$,mail.ru). Контактное лицо для переписки.

Поплаухина Татьяна Борисовна - кандидат технических наук, доцент кафедры нефтегазовых технологий (тел.:+007 912 881 79 39, e-mail: poplaukhinatb $($ gmail.com). Лузина Нина Геннадьевна - ведущий инженер отдела геолого-экономической оценки запасов месторождений (тел.: +007 342 233 6194 , e-mail: Nina.Luzina $a$,pnn.lukoil.com). Лобанов Дмитрий Сергеевич - инженер первой категории отдела геолого-экономической оценки запасов месторождений (тел.: +007 3422336193 , e-mail: Dmitrij.Lobanov@pnn.lukoil.com).

Емашов Роман Игоревич - начальник отдела геолого-экономической оценки запасов месторождений (тел.: +007 342233 61 99, e-mail: Roman.Emashov@pnn.lukoil.com). 


\section{Introduction}

In determination of remaining recoverable reserves (RRR) and oilfield development design, the main parameter driving the reliability of predictive calculations is accuracy of oil recovery factor (ORF) estimation. ORF value describes the share of initial recoverable reserves (IRR) which can be extracted out of the reservoir, from the initial oil in place (IOIP) in the course of development of the reservoir using state-of-the-art proven production technology and technique until economic limit is achieved, observing the requirements for protection of subsurface resources and the environment.

The most common method for ORF estimation is digital geological-hydrodynamic simulation (DGHS) which suggests simulation of oil reservoir development processes using software tools. This method has been implemented in the oil producing industry of Russia since 1990s, and is recommended for use by the current regulation [1]. DGHS provides a basis for calculation of various scenarios for development of oil reservoirs with varying number of production and injection wells, recovery rates etc. Examples of effective use of DGHS during oilfield development design are given in [2-4], including those applied in Perm Krai territory [5-10]. The most cost-effective oilfield development option must be approved by governmental authorities, each production object being attributed a design $\mathrm{ORF}_{\text {design }}$.

Undoubtedly, DGHS is the most reliable way for determining ORF, provided that qualified geological technology data is available. However, this method is very cost- and time-consuming, which leads to long intervals between $\mathrm{ORF}_{\text {design }}$ calculations, in most cases exceeding 10 years. As a result, over time the approved $\mathrm{ORF}_{\text {design }}$ can become largely outdated due to a variance between the design and actual development parameters and because of the changes in the economic conditions of development. Taking this into account, it is extremely important to establish in-operation controls for reliability of $\mathrm{ORF}_{\text {design }}$ in production objects, including its objective achievability within specified timeframe.

The subjectivity of ORF estimation in a production object is much higher than the subjectivity of IOIP estimation, at least due to its dependency on the well spacing and development system. Reliable ORF determination is only possible when using a scientifically justified methodological approach that takes into account the entirety of geological and technology conditions of oil production objects development.

\section{Impact of oil reserves geologic certainty degree on effectiveness of ORF in-operation control methods}

Several options of in-operation control are available for estimation of the approved ORFs: use of analog-statistical methods, displacement characteristics, oil production decline rate analysis. The methods are based on various physical regularities, their effectiveness to a large extent depending on the quality of input information and the stage of the production object development. Combined use of various approaches provides for a more reliable RRR estimation at the production objects.

Presently the in-operation control of hydrocarbon reserves' status is first of all associated with the geological and economic estimation of reserves (GEER) after the international standards. Regional oil producers perform GEER on an annual basis, the results being subject to approval by international auditors as an annual statement on reserves [11-13]. The authors find that the practice of in-operation (annual) control should be likewise in place for control of RRR in the oilfields approved according to the Russian classification.

A distinctive feature of the Russian (formerly Soviet) classification of hydrocarbon reserves is its focus on the degree of geologic certainty. The need to take into account the cost of reserves and to coordinate with the essential international classifications resulted in the modifications of the Russian classification that have been endorsed for implementation by the instruction of the RF government since 2002 [14]. Economic reserve estimation criteria must be among the priorities to help the state implement a more effective policy for stimulation of investments in oil and gas industry [15]. As of today, efforts in this area resulted in the "Classification of reserves and resources of oil and fuel gases" (2013) [16].

Such sources as $[15,17,18]$ pose the problems inherent in the current Russian classification, specifically its insufficient reliance on economic criteria. In-operation RRRs control, that takes into account the cost-effectiveness of their development, can significantly mitigate this problem. Effectiveness 
of these ORF control methods is to a large extent determined by the degree of geological certainty of reserves at the production object and, accordingly, the stage of its development.

Due to the diversity of geological conditions and applied development systems, it is not always possible to uniquely determine the development stage of a field [19]. This task usually requires a comprehensive account of such parameters as average production rate, water cutting of well production, well stock transfer to mechanical method of production, and gas factor growth [20]. For Perm Krai, as of 2018, the development stages of production objects had the following distribution: $9.6 \%$ objects - first stage; $21.6 \%$ - second stage; $66.1 \%$ - third stage; $2.7 \%$ - fourth stage.

\section{Use of analog-statistical methods in ORF estimation at production objects of early development stages}

Apparently, during the process of oilfield development ORF is influenced by many factors: geological (determined by the nature of production objects) and technological (determined by development conditions). At initial development stages, reliability of information is often low, which, among other things, strongly deteriorates DGHS quality. In the opinion of the authors, in such conditions the most effective option is in-operation estimation of ORF on the basis of analog-statistical models.

Analog-statistical methods for ORF estimation have been used in Perm region since 1980s [21-24]. An acknowledged advanced method is to use multivariate analog-statistical dependencies which help estimate $\mathrm{ORF}_{\text {st }}$ on the basis of a set of geological and technical indicators. The statistical methods are more resistant to the quality of input factual information and can therefore be implemented on the basis of the data of averaged geological and technological oilfield development characteristics. Thus it is possible to use these methods to control DGHS reliability, which is particularly important for the design of new oilfields and in-operation RRR estimation.

The most comprehensive analysis of $\mathrm{ORF}_{\text {st }}$ estimation effectiveness using the analog-statistical methods in Perm Krai territory is given in [25]. Its conclusion is that it is difficult to adjust methods developed for other territories (Kazakh Institute of Oil and Gas, API, LLC TatRITEKneft and others) to the needs of Perm Krai. As a more justified option, it is proposed to apply statistical dependencies to the analysis of "regional" fields development and for specific production objects (Bsh, Tl-Bb-Ml, T-Fm) [25]. Due to the long history of oilfields development in Perm Krai and a sufficiently large number of objects at late stages of recovery, it is possible to implement this statistical approach. Examples of successful use of statistical dependencies for Perm Krai production objects are given in [25-28].

Analog-statistical dependencies must be regularly updated. Otherwise, the statistical methods fail to take into account the new development technologies and cause a systematic ORF underestimation. Therefore, if calculations are performed using relatively "old" dependencies, it is crucial to compare the obtained $\mathrm{ORF}_{\mathrm{st}}$ estimates with the recently established $\mathrm{ORF}_{\text {design }}$ in analogous objects.

\section{Use of displacement characteristics in ORF estimation at production objects of late development stages}

In the case of steady dynamics of development parameters and remaining reserves recovery indicators, favorable conditions exist for the use of express estimation statistical models for solving inoperation design tasks [29]. One of the key characteristics influencing the forecast of reserves recovery in production objects is the dynamics of well production water cutting [30].

In $[31,32]$ models are provided for forecasting the dependency of water cutting dynamics $(w)$ on reserves recovery $(\eta)$ for reservoirs developed with flooding. Dependencies $w=f(\eta)$ are built separately for terrigenous and carbonate deposits in various oil viscosity ranges, taking into account the well stock movement dynamics and influence of well interventions (WI) to reduce water influx. Examples of calculation results are given in fig. 1, $a, b$.

For the vast majority of production objects (see fig. 1, a) there is an alignment between the estimated and actual dynamics $w=f(\eta)$. It is an evidence of reliable $\mathrm{ORF}_{\text {design }}$ estimation, which is a desirable condition for late development stages. Significant deviations from forecast models that are found in approximately $5 \%$ cases are related to incorrect IRR and, consequently, $\mathrm{ORF}_{\text {design }}$ 
estimation. Actual water cutting is above model values for production objects with reserves recovery and ORFdesign overestimated vs. actual.

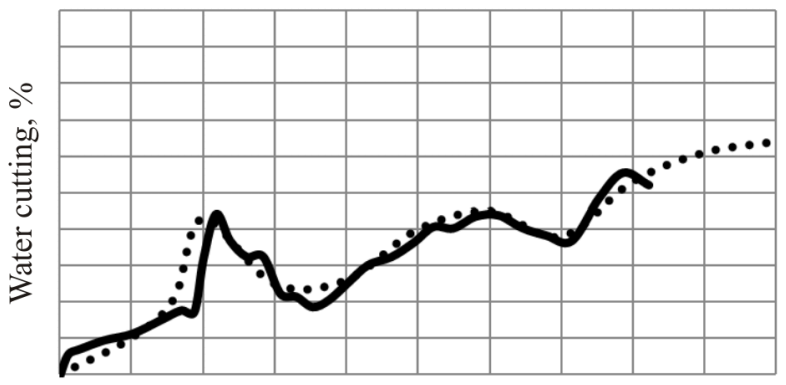

Recovery of reserves, $\%$

a

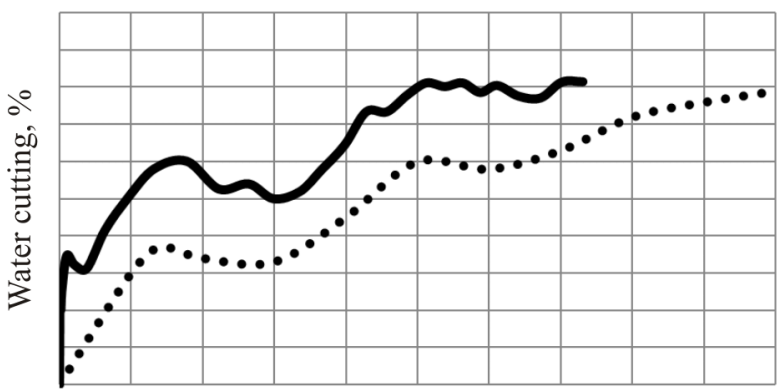

Recovery of reserves, $\%$

$b$

$\longrightarrow$ Actual $\cdots$... Forecast

Fig. 1. Dynamics of actual and model water cutting dependency on recovery of reserves at reliable $(a)$ and overestimated $(b)$ forecast of design ORF at the production object

In Fig. $1, b$ at $w=60 \%$ actual $\eta$ amounts to $19 \%$ versus $25 \%$ in $w=f(\eta)$ dependency. Hence, given unchanged cumulative oil production, IRR reduction factor can be estimated as $19 / 25=0.76$. Taking into account that IOIP at late development stages can be calculated quite accurately, the same factor (0.76) can be assumed for $\mathrm{ORF}_{\text {design }}$ reduction as well. Conversely, if actual water cutting is below model values given equal recovery, then actual IRR and $\mathrm{ORF}_{\text {design }}$ can be underestimated. In both cases, if there is a misalignment between actual and model $\mathrm{ORF}_{\text {design }}$ dynamics for production objects, it is advisable to reconsider $\mathrm{ORF}_{\text {design }}$ estimation results. Oil reserves recalculation for such objects following the results of $[31,32]$ has confirmed this conclusion.

As an alternative, other widely used characteristics of displacement can be used to determine the recoverable oil reserves according to their displacement nature directly, without taking into account the IOIP and ORF information.
For objects with water cutting above $50 \%$, the following displacement characteristics have proven effectiveness in Perm region:

$$
\begin{aligned}
& Q_{\mathrm{o}}=f\left(\ln Q_{\mathrm{f}}\right)-\text { B.F. Sazonova, } \\
& Q_{\mathrm{f}} / Q_{\mathrm{o}}=f\left(Q_{\mathrm{w}}\right)-\text { S.N. Nazarova }- \text { N.V. Sipacheva, } \\
& Q_{\mathrm{o}}=f\left(1 / Q_{\mathrm{f}}\right)-\text { G.S. Kambarova, }
\end{aligned}
$$

where $Q_{\mathrm{o}}, Q_{\mathrm{f}}, Q_{\mathrm{w}}$ - cumulative production of oil, fluid and water, respectively.

The results of analysis of multiple materials dedicated to ORF feasibility studies and projects for further development of reserves suggest that all characteristics have a number of drawbacks related to the fact that they have been received using certain assumptions. Therefore, it is advisable to establish the applicability limits for displacement characteristics in various geological and physical conditions and reserve development stages $[33,34]$.

\section{Using results of annual geologic and economic estimation of reserves}

GEER provides an annual correction of values and categories of reserves on the basis of comprehensive analysis of geologic, technological and economic contributors. Revision is mandatory for all information influencing the state of reserves and their categories: licenses, mine allotments, calculation or recalculation of reserves, drilling, testing, perforation, 3D seismic survey, hydrodynamic tests, well commissioning and decommissioning. These activities are directly or indirectly influenced by economic forces which have to be taken into account by introducing the remaining economic reserves (RER) indicator. RER is the part of the reserves which is cost effective to recover as of the date of GEER. In the periods of relatively low oil market value, subsurface users benefit from recovery of conventional hydrocarbon resources only. Oil price rise leads to an increase in the quantity of unconventional resources that can be added to RER category $[35,36]$.

Economic indicators include:

- macroeconomic parameters (Dollar exchange rate, Urals oil price);

- taxes and deductions (production tax);

- key production indicators (price of hydrocarbons, operational and capital costs, costs of well 
infrastructure development and abandonment, property tax).

For RER value determination, the concept of oil production profitability economic limit (EL), which represents the production volume below which the net cash flow from project implementation becomes negative. EL indicator value is composed from the hydrocarbons selling price, operational costs and production tax [37]. EL value is annually revised by the subsurface users on the basis of the current operational costs, price of hydrocarbons and tax imposed on their production.

IRR estimation is performed separately for the producing zone (PDP category, Proved Developed and Producing Reserves) and for the non-producing part of the reservoir. These are categories of proved reserves: Proved Developed Non-Producing Reserves (PDNP), Proved Undeveloped Reserves (PUD), and unproved reserves: Probable Reserves (PRB) and Possible Reserves (PSB) which will be treated as reserves by an international audit $[35,38]$. $\mathrm{ORF}_{\mathrm{GEER}}$ values have to be justified separately for these categories.

During international audits PDNP, PUD, PRB, PSB category reserves estimation usually draws on expert opinions. $\mathrm{ORF}_{\mathrm{GEER}}$ is determined for each nonproducing category of reserves based on the estimations obtained for the producing part of the reservoir taking into account the economic indicators. In the case of Perm region fields, "regional" statistical dependencies are used most of the time.

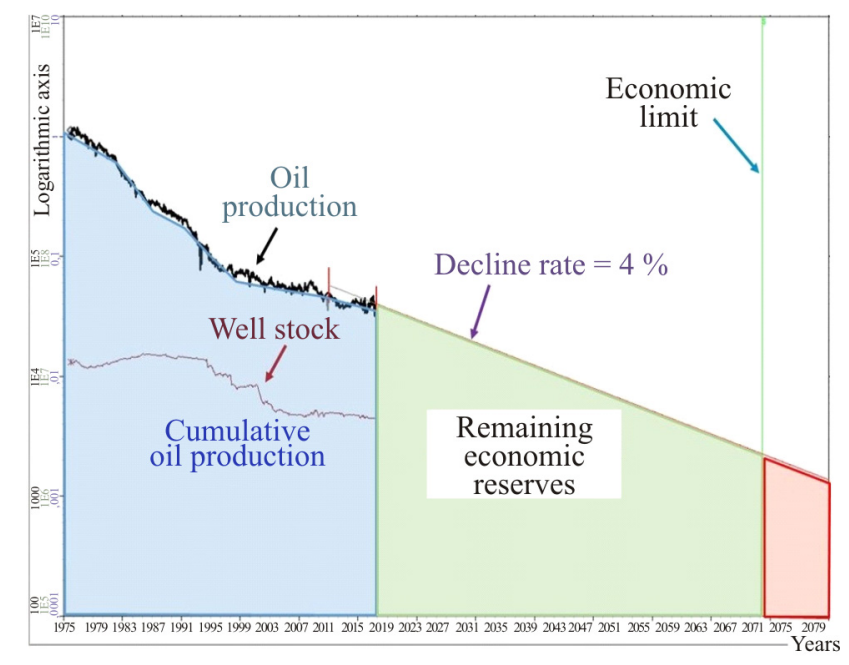

Fig. 2. Forecast estimation of oil production in MERAK PEEP software product

For the calculation of PDP category reserves, LUKOIL uses a software product MERAK PEEP
(Schlumberger) which generates monthly updates for such technological indicators of production objects as oil production, fluid production, injected water volume, current operating well stock (fig. 2).

Average oil production for the past year is extrapolated to the minimum profitable yield by exponential function of the production decline rate curve. Oil production decline rate $(\Delta q)$ is determined as actual for the preceding $3-5$ years or based on an expert opinion.

For objects at early stages of development, when production is unstable or unreliable due to a short operation period, the estimation should be preferably based on $\Delta q$ equal to $15 \%[39,40]$. For production objects at late stages of development, the basic principle of $\Delta q$ determination is based on studying RRR reduction dynamics for the preceding development period (5-10 years). RER values are calculated on the basis of $\Delta q$ until achievement of the economic production profitability limit (see fig. 2) [39-41]. Such approach for PDP category helps correct IRR taking into account the economic factors (cumulative production and RER).

WI planning for involvement of reserves into development is performed according to the company plans which can vastly differ from the design document provisions due to the current economic and technological situation. Initial yield for WI performed in PDP zone is determined on the basis of data analysis obtained from actually performed activities. The calculation has to take into account the specific indicators of RRR per well in WI area, as well as oil production decline rate and economic profitability limit [42].

In the global experience of the recent years, intelligent reservoir management technology gains an increasing popularity. The technology is based on continuous monitoring of production and injection wells operation through installation of sensors measuring their process parameters [43-47]. Such an approach improves integrity of actual production object information, significantly increases the accuracy of WI effectiveness forecast and, eventually, the RRR estimation reliability.

Thus, GEER results provide an in-operation estimation of reserves which account for the annual changes in the geological, technological and economic situation at each developed object. Unlike GEER, Russian classification takes these parameters into account only in the case of reserves recalculation 
or drawing up a new design document. Such annual estimation suggests the write-off of annual production from the State Register of Reserves. In fact such estimation does not meet the in-operation criteria as it does not reflect the current actual geological, technical and economic conditions of objects operation.

\section{Practical aspects of in-operation control of remaining recoverable reserves on the basis of integral analysis of technical and economic indicators of development}

For ORF in-operation estimation and control at various stages of oil production objects development, it is advisable to opt for the methods which are best suited to take into account the geological degree of certainty and reliability of geological, physical and technological nature of the objects.

At the first, initial stage of development many geological and physical parameters are determined on the basis of a small number of studies, often based on analogous objects. Technological indicators are studied during trial operation. ORF determination is possible using analog-statistical dependencies obtained for long-operated reservoirs of the region, with formulas that include geological and physical characteristics of formations and fluids. Such method has to take into account the approved $\mathrm{ORF}_{\text {design }}$ for neighboring fields with similar geological and field conditions of development.

Case study. For a Tournaisian object located in the Vostochno-Tavdinskaya area of Vinnikovskoe field at the initial stage of development, the design document stated an $\mathrm{ORF}_{\text {design }}$ equal to 0.43 . The use of a "regional" statistical dependency gives an $\mathrm{ORF}_{\text {st }}$ estimation of 0.302 . Let us now compare the results with four analogous objects for which average $\mathrm{ORF}_{\text {design }}=0.389 ; \mathrm{ORF}_{\text {st }}=0.276$; $\mathrm{ORF}_{\mathrm{GEER}}=0.329$. The integrated in-operation analysis suggests that $O R F_{\text {design }}$ is overestimated in the given conditions.

At the second stage of development, the geological degree of certainty of all input parameters is normally sufficient to create a reliable DGHS and, on its basis, the reservoir development plan. $\mathrm{ORF}_{\text {design }}$ approved by state authorities for a long term, or at times until the end of development, determines the choice of the development system and overall production dynamics of the object.
Case study. A Tournaisian object located in Sosnovskoe field with $\mathrm{ORF}_{\text {design }}=0.432$ is at the second stage of development. The use of a "regional" statistical dependency gives an $\mathrm{ORF}_{\text {st }}$ estimation of 0.353. Based on the results of economic estimation as of 1.01.2019, $\mathrm{ORF}_{\mathrm{GEER}}$ equal to 0.298 is forecasted. Three analogs are selected for the object, for which the average $\mathrm{ORF}_{\text {design }}=0.399 ; \mathrm{ORF}_{\mathrm{st}}=0.352 ; \mathrm{ORF}_{\mathrm{GEER}}=0.234$. Overall, an integrated analysis of the applied methods suggests that it is necessary to correct the development system for $\mathrm{ORF}_{\text {design }}$ to be achieved.

At the third stage, when all the basic characteristics of the reserves are reliably determined, the analysis of current state of development helps specify its effectiveness and plan its further improvement. The main $\mathrm{ORF}_{\text {design }}$ control method at this stage is building continuously operating DGHSs. For their control, analog-statistical dependencies can be used, involving the indicators descriptive of the development technology [25]. Effective use of displacement characteristics is based on the water cutting and reserve recovery indicators exceeding 40 and $50 \%$ [32]. Realistic estimation of reserves quality is achieved by GEER, especially in terms of planning the priority WIs at currently nonproducing reserves.

Case study. Object Bsh of Asulskoe uplift at Batyrbaiskoe field is at the third stage of development. Recovery from IRR is $62 \%$ at water cut $40 \% ; \mathrm{ORF}_{\text {design }}=0.382$. Based on the statistical dependency for carbonate deposits with reservoir pressure maintenance system, $\mathrm{ORF}_{\text {st }}$ is forecasted as equal to 0.264 . For the three displacement characteristics, the arithmetic mean ORF value amounts to 0.241. GEER results suggest that $\mathrm{ORF}_{\mathrm{GEER}}$ amounts to 0.247 , given this production rate and accounting for WI planned by the company. Integrated analysis with independent methods shows their high repeatability $(0.264 ; 0.241$ and 0.247$)$, which is much lower than the approved $\mathrm{ORF}_{\text {design, }}$ meaning that its achievability in the current state of development is doubtful.

The fourth, conclusive stage of development is usually characterized by reliable geological reserves and possesses a history of production over a long period. Further development of objects is performed in conditions of high water cutting, diminishing well stock, focal water flooding and a number of other phenomena typical of the 
conclusive stage. Many oilfields at this stage are being developed since 1950s-1970s, the time when control over technological production indicators was sporadic in general. For such "old" fields, it is quite challenging to include their history of development in DGHS process. Consequently, the estimation of recoverable reserves using hydrodynamic simulation should be combined with alternative ORF estimation methods.

At this stage of development, RRR calculation using displacement characteristics helps determine their value for the production object as a whole and for individual parts of the reservoir, wells and foci. The use of the results of geological and economic estimation of reserves in this period is of critical importance, since in-operation control of reserves and their profitability enables management of the producing well stock [42]. Annual calculation of economic recovery limit and economic water cut limit provides a basis for justified well stock shutdown, conservation and abandonment activities. This, in turn, enables operational cost improvement and makes oil production profitable over long periods of time.

Case study. Object Tl-Bb-Ml of Asulskoe uplift at Batyrbaiskoe field is under development since 1962 , recovery of reserves from IRR amounts to $81 \%$ at $\mathrm{ORF}_{\text {design }}=0.402$. Current water cut in wells is $42 \%$ (given historical maximum $58 \%$ ), a very low value for the fourth stage of development that gives a reason to suspect underestimation of actual IRRs. Using an analog-statistical dependency, as estimate of $\mathrm{ORF}_{\text {st }}=0.408$ was obtained for Visean deposits taking into account the technological development indicators. At high recovery and water cut, displacement characteristics can be quite informative; average ORF estimation for the three characteristics amounted to 0.493. GEER results suggest that, taking into account WI planned by the company, given the established production rate, $\mathrm{ORF}_{\mathrm{GEER}}=0.405$. Analysis of results using the three alternative estimation methods $(0.408 ; 0.493 ; 0.405)$ shows that $\mathrm{ORF}_{\text {design }}=0.402$ is achievable and can even be exceeded given the existing production effectiveness.

Using the same reservoir as an example, we shall now consider how RRR value is influenced by the annual production decline rate $(\Delta q)$, economic production profitability limit (EL) and well stock decrease. $\Delta q$ value for this production object during
2018 GEER was assumed equal to $8 \%$. Taking into account the stable high level of production, $\Delta q$ may be corrected downwards to $7 \%$. This leads to RRR increment of about $15 \%$. EL indicator for 2018 has decreased from 3.3 to $2.5 \mathrm{t} /$ day/well, which results in RRR increase by $1 \%$. Timely decommissioning of wells found unprofitable based on EL helps prolong the profitable period of reservoir development and obtain an additional $10 \%$ RRR. Thus, rational management of reserves at production objects significantly increases profitable RRRs and their ultimate oil recovery.

\section{Conclusions}

The main problem in estimating ORF using the method of geological and hydrodynamic simulation is its high cost that excludes in-operation control of the current hydrocarbon reserves. Over time, the approved ORFs can become considerably outdated due to the change in economic conditions of development or discrepancy between the actual and design development conditions. Therefore, for the reliable estimation of production objects' RRRs it is crucial to establish in-operation control of ORFs validity, including their objective achievability within specified time frame.

In-operation controls can comprise methods based on generalization of various physical regularities (analog statistics, displacement characteristics, production decline rate analysis). Advisability of a method depends on the stage of development and degree of geological certainty. For early stages of development, it is recommended to use multivariate analog-statistical dependencies based on the geological indicators constructed for specific production objects. At later stages, higher reliability can be provided by methods based on displacement characteristics and oil production decline rate, taking into account the economic development profitability limit. Statistical dependencies alongside geological and technological development indicators can be used as a control.

Integrated use of various methodological approaches improves RRR estimation reliability at production objects. A comparative analysis between $\mathrm{ORF}_{\text {design }}$ and results of estimation that employed alternative methods helps forecast its current achievability and introduce necessary corrections into the development system. 


\section{References}

1. RD 153-39.0-047-00. Reglament po sozdaniiu postoianno deistvuiushchikh geologo-tekhnologicheskikh modelei neftianykh i gazoneftianykh mestorozhdenii [Regulation on the creation of permanent geological and technological models of oil and gas and oil fields]. Moscow, Ministerstvo topliva i energetiki Rossiiskoi Federatsii, 2000, $130 \mathrm{p}$.

2. Shalamova V.I., Vershinina I.V., Kovalenko M.A., Snytko N.N. Postroenie geologo-gidrodinamicheskoi modeli $\mathrm{v}$ usloviiakh fliuidalnoi neodnorodnosti produktivnykh plastov Imilorskogo mestorozhdeniia [Hydrodynamic model construction in conditions of fluidal heterogeneity of Imilor deposit productive formations]. Geology, Geophysics and Development of Oil and Gas Fields, 2017, no.9, pp.42-46.

3. Mett D.A., Sukhodanova S.S., Aubakirov A.R. Opyt postroeniia i verifikatsii variativnykh geologogidrodinamicheskikh modelei na primere tiumenskikh otlozhenii Novo-Moskovskogo mestorozhdeniia [Experience of construction and verification of variative geological-hydrodynamic models on the example of the Tyumen deposits of the NovoMostovskoye deposit]. Geology, Geophysics and Development of Oil and Gas Fields, 2018, no.2, pp.32-35. DOI: 10.30713/2413-5011-2018-2-32-35

4. Dikalov D.V. Kompleksnyi podkhod k sozdaniiu postoiannodeistvuiushchei geologotekhnologicheskoi modeli na primere ZapadnoTugrovskogo mestorozhdeniia [Comprehensive approach to the construction of a permanently working geological-technological model on the example of the Western-Tugrovsky deposit]. Geology, Geophysics and Development of Oil and Gas Fields, 2018, no.9, pp.34-40. DOI: 10.30713/2413-5011-2018-9-34-40

5. Iliushin P.Iu., Turbakov M.S., Galkin S.V., Kern D.A. Modelirovanie vodogazovogo vozdeistviia pri razrabotke Zmeevskogo neftianogo mestorozhdeniia [Simulation of the water-alternated-gas injection for Zmeevskoye oil field development]. Oil industry, 2012, no.11, pp.116-117.

6. Deriushev A.B. On the need to compare geological and hydrodynamic characteristics of a deposit using 3D modelling as exemplified by the T12-b pay bed of the Nozhovskoie oil field. Perm Journal of Petroleum and
Mining Engineering, 2014, no.13, pp.15-25. DOI: $10.15593 / 2224-9923 / 2014.13 .2$

7. Latysheva M.V., Ustinova Iu.V., Kashevarova V.V., Potekhin D.V. Improvement of hydrodynamic simulation using advanced techniques of hydrodynamic well data processing (exemplified by Ozernoe field). Perm Journal of Petroleum and Mining Engineering, 2015, no. 15, pp.73-80. DOI: $10.15593 / 2224-9923 / 2015.15 .8$

8. Cherepanov S.S., Chumakov G.N., Galkin S.V. Vozmozhnosti ucheta treshchinovatosti kollektorov pri geologo-gidrodinamicheskom modelirovanii razrabotki zalezhei $\mathrm{s}$ zavodneniem plastov [Possibilities of accounting of reservoirs' fracturing when geologicall-hydrodynamic modeling of deposits development with formations waterflooding]. Oilfield engineering, 2016, no.8, pp.5-8.

9. Repina V.A. How to consider rock density in fluid flow model of oil fields during permeability modeling. Perm Journal of Petroleum and Mining Engineering, 2017, vol.16, no.2, pp.104-112. DOI: $10.15593 / 2224-9923 / 2017.2 .1$

10. Repina V.A., Galkin V.I., Galkin S.V. Primenenie kompleksnogo ucheta petrofizicheskikh kharakteristik pri adaptatsii geologo-gidrodinamicheskikh modelei (na primere vizeiskoi zalezhi Gondyrevskogo mestorozhdeniia nefti) [Complex petrophysical correction in the adaptation of geological hydrodynamic models (on the example of Visean pool of Gondyrev oil field)]. Zapiski Gornogo instituta, 2018, vol.231, pp.268-274. DOI: 10.25515/PMI.2018.3.268

11. Sistema upravleniia resursami i zapasami zhidkikh, gazoobraznykh i tverdykh uglevodorodov SPE-PRMS [Resource management system for liquid, gaseous and solid hydrocarbons SPE-PRMS], available at: https://www.spe.org/ industry/docs/PRMgmtSystem_V1.01_RUS-FINAL.pdf (accessed 17 July 2019).

12. Khalimov K.E. Perekhod na mezhdunarodnuiu klassifikatsiiu zapasov nefti - trebovanie vremeni [Transition to the international classification of oil reserves is a requirement of the time]. Neft, gaz i biznes, 2002, no.5, pp.10-13.

13. Khalimov K.E. Evoliutsiia otechestvennoi klassifikatsii nefti i gaza [The evolution of the domestic classification of oil and gas]. Ed. E.M. Khalimova. Moscow, Nedra-Biznestsentr, 2003, pp. 31-37. 
14. Gabrieliants G.A., Kovalenko E.G., Poroskun V.I. Novaia klassifikatsiia zapasov i resursov nefti i goriuchego gaza [New classification of reserves and resources of oil and combustible gas]. Tekhnologii TEK, 2001, no.4, pp. 20-25.

15. Varlamov A.I., Petersile V.I., Poroskun V.I. $\mathrm{O}$ novoi klassifikatsii zapasov i resursov uglevodorodov [Concerning new hydrocarbon reserves and resources classification]. Oil and Gas Geology, 2016, no.1, pp.89-94.

16. Metodicheskie rekomendatsii po primeneniiu klassifikatsii zapasov i resursov nefti i goriuchikh gazov. trebovaniia k sostavu i pravilam oformleniia predstavliaemykh na gosudarstvennuiu ekspertizu materialov po podschetu zapasov nefti i goriuchikh gazov [Guidelines for the application of the Classification of reserves and resources of oil and combustible gases. Requirements for the composition and rules for the design of materials submitted for state examination for the calculation of oil and combustible gas reserves]. Moscow, Minprirody Rossii, 2016.

17. Zakirov S.N., Indrupskii I.M. et al. Problemy novoi klassifikatsii zapasov i neftegazovogo nedropolzovatelia [Problems of the new classification of reserves and oil and gas subsoil users]. Neftegazovaia vertikal, 2015, no.22, pp. 69-75.

18. Muslimov R.Kh. Kak mozhet povliiat novaia klassifikatsiia zapasov i resursov nefti i goriuchikh gazov na rabotu neftianoi otrasli? [How the new classification of reserves and resources of oil and combustible gases can influence the work of petroleum branch?]. Oil industry, 2016, no.6, pp.34-38.

19. Muslimov R.Kh. Metody povysheniia effektivnosti razrabotki neftianykh mestorozhdenii na pozdnei stadii [Methods of increasing an oil fields development efficiency at a late stage]. Oil industry, 2008, no.3, pp.30-34.

20. Galkin S.V., Koshkin K.A., Poplaukhina T.B. Analiz struktury fonda ekspluatatsionnykh obektov pri operativnoi otsenke ostatochnykh zapasov nefti [Analysis of structure of operational objects fund during operational estimation of residual oil stockpiles]. Geology, Geophysics and Development of Oil and Gas Fields, 2009, no. 10, pp.37-39.

21. RD 39-0147035-214-86. Metodicheskoe rukovodstvo po raschetu koeffitsientov izvlecheniia nefti iz nedr [Guidelines for the calculation of oil recovery ratios from subsoil]. Moscow, $1986,253 \mathrm{p}$.

22. Gorovov V.I., Raspopov A.V., Filonov M.I. Programma rascheta koeffitsienta izvlecheniia nefti KING. Spravochnoe rukovodstvo polzovatelia. 577199.00.105 [The KING oil recovery ratio calculation program. Reference user guide. 577199.00.105]. Perm, KIVTs, 1990, pp. 10-15.

23. Savich A.I. Otsenka koeffitsienta izvlecheniia nefti na stadii promyshlennoi razvedki i pervogo podscheta zapasov nefti zalezhei pri zavodnenii [Estimation of oil recovery coefficient at the stage of industrial exploration and the first calculation of oil reserves of deposits during flooding]. Voprosy osvoeniia neftianykh zalezhei Permskogo Priuralia, Trudy VNIIOEGN. Moscow, 1990, pp.9-13.

24. Gorovov V.I., Raspopov A.V., Shustef I.N. Priblizhennyi metod rascheta pokazatelei razrabotki mestorozhdenii [An approximate method for calculating field development indicators]. Oil industry, 1988, no.6, pp.25-27.

25. Koshkin K.A., Galkin S.V. Oil recovery forecast during reevaluation of visean clastic deposits reserves of north-east Volga-Ural oil and gas province. Perm Journal of Petroleum and Mining Engineering, 2015, no.17, pp.16-23. DOI: $10.15593 / 2224-9923 / 2015.17 .2$

26. Galkin V.I., Savich A.I., Akimov I.A. Differentsiatsiia vizeiskikh obektov razrabotki dlia postroeniia modelei opredeleniia koeffitsientov izvlecheniia nefti [Differentiation of Visean productive formations for construction of statistical models to determine oil recovery factors]. Izvestiia vysshikh uchebnykh zavedenii. Neft i gaz, 2007, no.5, pp.9-14.

27. Galkin S.V., Poplaukhina T.B., Raspopov A.V., Khizhniak G.P. Otsenka koeffitsientov izvlecheniia nefti dlia mestorozhdenii Permskogo kraia na osnove statisticheskikh modelei [Estimation of oil recovery ratios for Permskiy Region fields on the basis of statistical models]. Oil industry, 2009, no.4, pp.38-39.

28. Galkin V.I., Galkin S.V., Voevodkin V.L. Postroenie statisticheskikh modelei otsenki koeffitsienta izvlecheniia nefti dlia ekspluatatsionnykh obektov Permskogo prikamia [Construction of the statistical models of the estimation of current oil recovery for the operational objects of Perm region]. Oil industry, 2011, no.2, pp.86-88. 
29. Baturin Iu.A. K voprosu obosnovaniia kin pri podschete zapasov i proektirovanii razrabotki neftegazovykh mestorozhdenii [On justification of oil recovery factor for reserves estimation and oil-and-gas field development designing]. Vestnik TsKR Rosnedra. Moscow, 2011, no.1, pp.2-5.

30. Dake L.P. The practice of reservoir engineering. Elsevier, 1994, 525 p.

31. Galkin S.V., Iliushin P.Iu. Prognoz dinamiki obvodnennosti produktsii skvazhin $\mathrm{v}$ razlichnykh geologo-tekhnologicheskikh usloviiakh razrabotki neftianykh mestorozhdenii [Forecast of wells water cut in different geological and technological conditions of oil field development]. Oil industry, 2011, no.10, pp.22-24.

32. Iliushin P.Iu., Galkin S.V., Poplaukhina T.B., Luzina N.G. Razrabotka metodiki opredeleniia dinamiki obvodneniia produktsii skvazhin s uchetom vliianiia geologicheskikh i tekhnologicheskikh pokazatelei [Development of the methodology for well drowning assessment with regard to geological and technological parameters]. Oil industry, 2012, no.4, pp.108-110.

33. Amelin I.D., Surguchev M.L., Davydov A.V. Prognoz razrabotki neftianykh zalezhei na pozdnei stadii [Late Stage Oil Development Forecast]. Moscow, Nedra, 1994, pp.162-170.

34. Merkulova L.I., Ginzburg A.A. Graficheskie metody analiza pri dobyche nefti [Graphical methods of analysis in oil production]. Moscow, Nedra, 1986, pp. 3-10.

35. Hayder G.M. World oil reserves: problems in definition and estimation. OPEC Review, 2000, vol.24, pp. 16-25.

36. Auditing standards for reserves. World petroleum congress, available at: www.worldpetroleum.org (accessed 12 July 2019).

37. Poplaukhina T.B., Iakimova I.V., Matveikina T.N., Savich A.I. Koeffitsient izvlecheniia nefti: raschet i realnost [Oil recovery ratio: calculation and reality]. Geology, Geophysics and Development of Oil and Gas Fields, 2005, no.5-6, pp.16-20.

38. Laherrere J.H. Reserve growth: Technological progress, or bad reporting and bad arithmetic. Geopolitics of Energy, 1999, vol.22, pp. 47-60.

39. Poplaukhina T.B., Mokrushina S.S., Krylov D.Iu., Khomutova A.V. Opredelenie godovykh tempov padeniia dobychi nefti po obektam razrabotki mestorozhdenii ZAO "LUKOIL-Perm" dlia vypolneniia geologo-ekonomicheskoi otsenki zapasov po klassifikatsii SPE [Determination of the annual rate of oil production decline at oilfield production objects of CJSC LUKOIL-Perm for performing geological and economic assessment of reserves according to SPE classification]. Neft i gaz, 2004, no5, pp.92-100.

40. Poplaukhina T.B., Mokrushina S.S., Khomutova A.V., Krasnoperov E.A. Obosnovanie prognoznykh tempov padeniia dobychi nefti dlia geologo-ekonomicheskoi otsenki zapasov [Justification of the predicted rate of decline in oil production for geological and economic assessment of reserves]. Geology, Geophysics and Development of Oil and Gas Fields, 2005, no.5-6, pp.7-11.

41. Poplaukhina T.B., Khomutova A.V. Opyt provedeniia geologo-ekonomicheskoi otsenki zapasov nefti i gaza po mezhdunarodnym standartam $\mathrm{v}$ Permskom regione [Experience in geological and economic assessment of oil and gas reserves by international standards in the Perm region]. Oil industry, 2009, no.4, pp. 108-110.

42. Poplaukhina T.B., Krylov D.Iu., Khomutova A.V. Sozdanie i primenenie algoritmov vybytiia fonda skvazhin $\mathrm{v}$ zavisimosti ot uslovii razrabotki po mestorozhdeniiam ZAO "LUKOIL-PERM" [Creation and application of well stock retirement algorithms depending on the development conditions for the fields of LUKOIL-Perm CJSC]. Neft $i \mathrm{gaz}$, 2004, no.5, pp.79-87.

43. Alvarado V., Manrique E. Enhanced oil recovery: an updated review. Energies, 2010, 3, pp.1529-1575. DOI: http://dx.doi.org/10.3390/en3091529

44. Peter R. Rose risk analysis and management of petroleum exploration ventures - AAPG. Oklahoma, Tulsa, 2001, p. 164. DOI: 10.1306/Mth12792

45. Sandrea I., Sandrea R. Recovery factors leave vast target for EOR technologies. Oil Gas J, 2007, 105, pp.44-47.

46. Tarek Ahmed. Reservoir engineering handbook. $5^{\text {th }}$ ed. 2019.1524. DOI: http://doi.org/10.1016/C2016-0-04718-6

47. Advanced resources international. Undeveloped domestic oil resources: the foundation for increased oil production and a viable domestic oil industry. US Department of Energy, Office of Fossil Energy - Office of Oil and Natural Gas. 2006, available at: https://web.archive.org/web/2009042 5063318/http://www.fossil.energy.gov/programs/oilgas/ publications/eor_co2/Undeveloped_Oil_Document.pdf (accessed 12 July 2019). 


\section{Библиографический список}

1. РД 153-39.0-047-00. Регламент по созданию постоянно действующих геолого-технологических моделей нефтяных и газонефтяных месторождений. - М.: Министерство топлива и энергетики Российской Федерации, 2000. $130 \mathrm{c}$.

2. Построение геолого-гидродинамической модели в условиях флюидальной неоднородности продуктивных пластов Имилорского месторождения / В.И. Шаламова, И.В. Вершинина, М.А. Коваленко, Н.Н. Снытко // Геология, геофизика и разработка нефтяных и газовых месторождений. - 2017. - № 9. - С. 42-46.

3. Метт Д.А., Суходанова С.С., Аубакиров А.Р. Опыт построения и верификации вариативных геолого-гидродинамических моделей на примере тюменских отложений НовоМосковского месторождения // Геология, геофизика и разработка нефтяных и газовых месторождений. - 2018. - № 2. - С. 32-35. DOI: $10.30713 / 2413-5011-2018-2-32-35$

4. Дикалов Д.В. Комплексный подход к созданию постоянно действующей геологотехнологической модели на примере ЗападноТугровского месторождения // Геология, геофизика и разработка нефтяных и газовых месторождений. - 2018. - № 9. - С. 34-40. DOI: 10.30713/2413-5011-2018-9-34-40

5. Моделирование водогазового воздействия при разработке Змеевского нефтяного месторождения / П.Ю. Илюшин, М.С. Турбаков, С.В. Галкин, Д.А. Керн // Нефтяное хозяйство. 2012. - № 11. - С. 116-117.

6. Дерюшев А.Б. О необходимости сопоставления геологических и гидродинамических характеристик залежей по данным трехмерного моделирования на примере продуктивного пласта Тл2-б Ножовского месторождения нефти // Вестник Пермского национального исследовательского политехнического университета. Геология. Нефтегазовое и горное дело. - 2014. - № 13. C. 15-25. DOI: $10.15593 / 2224-9923 / 2014.13 .2$

7. Повышение эффективности гидродинамического моделирования посредством применения усовершенствованных методик обработки данных гидродинамических исследований скважин (на примере Озерного месторождения) / М.В. Латышева, Ю.В. Устинова, В.В. Кашеварова,
Д.В. Потехин // Вестник Пермского национального исследовательского политехнического университета. Геология. Нефтегазовое и горное дело. - 2015. - № 15. - С. 73-80. DOI: $10.15593 / 2224-9923 / 2015.15 .8$

8. Черепанов С.С., Чумаков Г.Н., Галкин С.В. Возможности учета трещиноватости коллекторов при геолого-гидродинамическом моделировании разработки залежей с заводнением пластов // Нефтепромысловое дело. - 2016. - № 8. C. 5-8.

9. Репина В.А. Возможность учета плотности породы при моделировании проницаемости в геолого-гидродинамической модели нефтяных месторождений // Вестник Пермского национального исследовательского политехнического университета. Геология. Нефтегазовое и горное дело. - 2017. - Т. 16, № 2. - С. 104-112. DOI: $10.15593 / 2224-9923 / 2017.2 .1$

10. Репина В.А., Галкин В.И., Галкин С.В. Применение комплексного учета петрофизических характеристик при адаптации геологогидродинамических моделей (на примере визейской залежи Гондыревского месторождения нефти) // Записки Горного института. - 2018. T. 231. - C. 268-274. DOI: 10.25515/PMI.2018.3.268

11. Система управления ресурсами углеводородов SPE-PRMS [Электронный ресурс] / Общество инженеров по оценке запасов нефти и газа США (SPEE). - URL: https://www.spe.org/ industry/docs/PRMgmtSystem_V1.01_RUS-FINAL.pdf (дата обращения: 17.07.2019).

12. Халимов К.Э. Переход на международную классификацию запасов нефти - требование времени // Нефть, газ и бизнес. - 2002. - № 5. C. $10-13$.

13. Халимов К.Э. Эволюция отечественной классификации нефти и газа / под ред. Э.М. Халимова. - М.: Недра-Бизнес центр, 2003. C. 31-37.

14. Габриэлянц Г.А., Коваленко Е.Г., Пороскун В.И. Новая классификация запасов и ресурсов нефти и горючего газа // Технологии ТЭК. - 2001. - № 4. - C. 20-25.

15. Варламов А.И., Петерсилье В.И., Пороскун В.И. О новой классификации запасов и ресурсов углеводородов // Геология нефти и газа. - 2016. - № 1. - С. 89-94. 
16. Методические рекомендации по применению Классификации запасов и ресурсов нефти и горючих газов. Требования к составу и правилам оформления представляемых на государственную экспертизу материалов по подсчету запасов нефти и горючих газов. М.: Минприроды России, 2016.

17. Проблемы новой классификации запасов и нефтегазового недропользования / С.Н Закиров, И.М. Индрупский [и др.] // Нефтегазовая вертикаль. - 2015. - № 22. - С. 69-75.

18. Муслимов Р.Х. Как может повлиять новая классификация запасов и ресурсов нефти и горючих газов на работу нефтяной отрасли? // Нефтяное хозяйство. - 2016. - № 6. - С. 34-38.

19. Муслимов P.X. Методы повышения эффективности разработки нефтяных месторождений на поздней стадии // Нефтяное хозяйство. -2008 . - № 3. - С. 30-34.

20. Галкин С.В., Кошкин К.А., Поплаухина Т.Б. Анализ структуры фонда эксплуатационных объектов при оперативной оценке остаточных запасов нефти // Геология, геофизика и разработка нефтяных и газовых месторождений. 2009. - № 10. - С. 37-39.

21. РД 39-0147035-214-86. Методическое руководство по расчету коэффициентов извлечения нефти из недр. - М., 1986. -253 с.

22. Горовов В.И., Распопов А.В., Филонов М.И. Программа расчета коэффициента извлечения нефти «КИНГ»: справочное руководство пользователя: 577199.00.105 / КИВЦ. - Пермь, 1990. - C. $10-15$.

23. Савич А.И. Оценка коэффициента извлечения нефти на стадии промышленной разведки и первого подсчета запасов нефти залежей при заводнении // Вопросы освоения нефтяных залежей Пермского Приуралья: тр. ВНИИОЭГН. - М., 1990. - С. 9-13.

24. Горовов В.И., Распопов А.В., Шустеф И.Н. Приближенный метод расчета показателей разработки месторождений // Нефтяное хозяйство. 1988. - № 6. - С. 25-27.

25. Кошкин К.А., Галкин С.В. Возможности прогноза нефтеизвлечения при переоценке запасов визейских терригенных залежей северо-востока Волго-Уральской нефтегазоносной провинции // Вестник Пермского национального исследовательского политехнического университета. Геология. Нефтегазовое и горное дело. - 2015. - № 17. - С. 16-23. DOI: $10.15593 / 2224-9923 / 2015.17 .2$

26. Галкин В.И., Савич А.И., Акимов И.А. Дифференциация визейских объектов разработки для построения моделей определения коэффициентов извлечения нефти // Известия высших учебных заведений. Нефть и газ. 2007. - № 5. - С. 9-14.

27. Оценка коэффициентов извлечения нефти для месторождений Пермского края на основе статистических моделей / С.В. Галкин, Т.Б. Поплаухина, А.В. Распопов, Г.П. Хижняк // Нефтяное хозяйство. - 2009. - № 4. - С. 38-39.

28. Галкин В.И., Галкин С.В., Воеводкин В.Л. Построение статистических моделей оценки коэффициента извлечения нефти для эксплуатационных объектов Пермского Прикамья // Нефтяное хозяйство. - 2011. - № 2. - С. 86-88.

29. Батурин Ю.А. К вопросу обоснования КИН при подсчете запасов и проектировании разработки нефтегазовых месторождений // Вестник ЦКР Роснедра. - 2011. - № 1. C. $2-5$.

30. Dake L.P. The practice of reservoir engineering. - Elsevier, 1994. $-525 \mathrm{p}$.

31. Галкин С.В., Илюшин П.Ю. Прогноз динамики обводненности продукции скважин в различных геолого-технологических условиях разработки нефтяных месторождений // Нефтяное хозяйство. -2011 . - № 10. - С. 22-24.

32. Разработка методики определения динамики обводнения продукции скважин с учетом влияния геологических и технологических показателей / П.Ю. Илюшин, С.В. Галкин, Т.Б. Поплаухина, Н.Г. Лузина // Нефтяное хозяйство. - 2012. - № 4. - С. 108-110.

33. Амелин И.Д., Сургучев М.Л., Давыдов А.В. Прогноз разработки нефтяных залежей на поздней стадии. - М.: Недра, 1994. - С. 162-170.

34. Меркулова Л.И., Гинзбург А.А. Графические методы анализа при добыче нефти. - М.: Недра, 1986. - C. 3-10.

35. Hayder G.M. World oil reserves: problems in definition and estimation // OPEC Review. - 2000. Vol. 24. - P. 16-25.

36. Auditing standards for reserves // World Petroleum Congress. - URL: www.worldpetroleum.org (дата обращения: 12.07.2019).

37. Коэффициент извлечения нефти: расчет и реальность / Т.Б. Поплаухина, И.В. Якимова, 
Т.Н. Матвейкина, А.И. Савич // Геология, геофизика и разработка нефтяных месторождений. -2005 . № 5-6. - C. 16-20.

38. Laherrere J.H. Reserve growth: technological progress, or bad reporting and bad arithmetic // Geopolitics of Energy. - 1999. - Vol. 22. P. 47-60.

39. Определение годовых темпов падения добычи нефти по объектам разработки месторождений ЗАО «ЛУКОЙЛ-ПЕРМЬ» для выполнения геолого-экономической оценки запасов по классификации SPE / Т.Б. Поплаухина, С.С. Мокрушина, Д.Ю. Крылов, А.В. Хомутова // Нефть и газ. - 2004. - № 5. - С. 92-100.

40. Поплаухина Т.Б., Хомутова А.В. Опыт проведения геолого-экономической оценки запасов нефти и газа по международным стандартам в Пермском крае // Нефтегазовое дело. - 2009. - № 4. - Р. 108-110.

41. Разработка методики определения динамики обводнения продукции скважин с учетом влияния геологических и технологических показателей / П.Ю. Илюшин, С.В. Галкин, Т.Б. Поплаухина, Н.Г. Лузина // Нефтяное хозяйство. - 2012. - № 4. - С. 108-110.

42. Поплаухина Т.Б., Крылов Д.Ю., Хомутова А.В. Создание и применение алгорит- мов выбытия фонда скважин в зависимости от условий разработки по месторождениям ЗАО «ЛУКОЙЛ-ПЕРМЬ» // Нефть и газ. - 2004. № 5. - C. 79-87.

43. Alvarado V., Manrique E. Enhanced oil recovery: an updated review // Energies. - 2010. - 3. P. 1529-1575. DOI: http://dx.doi.org/10.3390/en3091529

44. Peter R. Rose risk analysis and management of petroleum exploration ventures AAPG. Oklahoma, Tulsa, 2001. - 164 p. DOI: 10.1306/Mth12792

45. Sandrea I., Sandrea R. Recovery factors leave vast target for EOR technologies // Oil Gas J. 2007. - 105. - P. 44-47.

46. Tarek Ahmed. Reservoir engineering handbook. $\quad-5^{\text {th }}$ ed. - 2019. DOI: http://doi.org/10.1016/C2016-0-04718-6.

47. Advanced Resources International. Undeveloped domestic oil resources: the foundation for increased oil production and a viable domestic oil industry [Электронный ресурс] / US Department of Energy, Office of Fossil Energy Office of Oil and Natural Gas. 2006. URL: https://web.archive.org/web/20090425063318/ http://www.fossil.energy.gov/programs/oilgas/publicati ons/eor_co2/Undeveloped_Oil_Document.pdf (дата обращения: 12.07.2019).

Please cite this article in English as:

Galkin S.V., Poplaukhina T.B., Luzina N.G., Lobanov D.S., Emashov R.I. Possibilities for in-operation control of remaining recoverable reserves at various stages of oil production objects development. Perm Journal of Petroleum and Mining Engineering, 2019, vol.19, no.4, pp.322-334. DOI: 10.15593/2224-9923/2019.4.2

Просьба ссылаться на эту статью в русскоязычных источниках следующим образом:

Возможности оперативного контроля остаточных извлекаемых запасов на различных стадиях разработки нефтяных эксплуатационных объектов / С.В. Галкин, Т.Б. Поплаухина, Н.Г. Лузина, Д.С. Лобанов, Р.И. Емашов // Вестник Пермского национального исследовательского политехнического университета. Геология. Нефтегазовое и горное дело. 2019. - Т.19, №4. - C.322-334. DOI: 10.15593/2224-9923/2019.4.2 